\author{
PAWEŁ BORTKIEWICZ \\ Adam Mickiewicz University in Poznan \\ Faculty of Theology
}

\title{
"The genealogy of the person is inscribed in the very biology of generation". Towards the heart of the dispute on Humanae vitae
}

\section{Discussion around Humanae vitae}

The encyclical of St. Paul VI Humanae vitae has been still under discussion since its publication in 1968. This discussion becomes more intense on the occasion of the subsequent anniversaries of the publication of the document. ${ }^{1}$

It is pointed out that during the Second Vatican Council, some of the Council Fathers, such as Cardinals Leger from Canada, Suenens from Belgium, and Patriarch Maxim proposed re-reading the encyclical and confronting it with the results of scientific research published at that time, especially those concerning demography. At the same time, the group of the protagonists of the encyclical pointed to the issue of faithfulness of the Church to the spirit of truth (Truth), and this faithfulness can not give way to submissiveness to the spirit of time, equated in an ambiguous and often naive manner with progress.

Particularly clearly, the dilemmas caused by the encyclical manifested within the Catholic Church in Germany. Immediately after the promulgation

\footnotetext{
${ }^{1}$ Cf. e.g. R. Shaw, Message Refused: Humanae vitae, 40 Years Later, https://www.crisismaga zine.com/2008/message-refused-humanae-vitae-40-years-later [accessed: 27.04.2018]; K. Mahoney, Humanae vitae: 40 years later, still about love, https://www.catholicnewsagency.com/resources/lifeand-family/humanae-vitae/humanae-vitae-40-years-later-still-about-love [accessed: 27.04.2018]; D. Gyapong, Humanae vitae receives new respect 40 years later, https://www.catholicregister.org/home/ international/item/9652-humanae-vitae-receives-new-respect-40-years-later [accessed: 27.04.2018]; $\mathrm{S}$. Tyree, The vindication of Humanae vitae: 40 years later, http://www.stltoday.com/lifestyles/faithand-values/civil-religion/the-vindication-of-humanae-vitae-years-later/article_369a1cf3-8558-59889c70-50ee177b4fbd.html [accessed: 27.04.2018].
} 
of the encyclical on July 25, 1968, the German bishops gathered at an extraordinary session of the episcopate and after the stormy debates published the so-called "Statement from Königstein" (Königsteiner Erklärung). The document was supposed to be an attempt to reconcile the supporters and opponents of the papal document. The key accent was placed in the superior character of Catholics' conscience when planning a family. If this criterion is accepted, it may turn out to be risky, especially in view of some aspects of the so-called "new moral theology". As an example, here is the conception of the German moral theologian Bernard Häring, who in his textbook "Liberi e fedeli in Cristo" presented the concept of "interconnectedness of consciences". The idea of mutual co-binding should, in his opinion, play the role of the highest authority, distancing even the Magisterium of the Church. "Besides of God, conscience is the supreme authority for everyone." (page 339). This means a distance from the Church's teaching, which offers only dry formulas and sclerotic laws (ibidem). On the other hand, conscience "achieves its fullness in reciprocity with the consciences of others".

Perhaps the expression of this "co-binding of consciences" was to be the proposed new formula for the creation of papal documents, consisting in the presentation of surveys and the construction of master's standards based on the created consensus in a given scope. ${ }^{2}$ The promotion of conscience was done in the name of the absolutization of the freedom of human self-determination at the expense of the moral law, and consequently at the expense of the integral truth about human existence. In the background of these views, there was the conception of freedom in the spirit of existentialist philosophy. In this light, it appears that the essence of the moral response to God is freedom and creativity, but this in turn means that the essence of the answer is reduced to the elements of psychological experience. This, however, means a trap of an invincible dilemma: "if a man freely and creatively decided to refuse to answer God, how to assess the essence of this act, when freedom determines its value? The absolutization of freedom must lead to questioning the very foundations of ethics". 3

Belgian bishops acted similarly to German bishops. Episcopal views were strongly supported by some theologians. The discussion quickly expanded from a purely ethical level (regarding the sphere of conjugal ethics and sexual

${ }^{2}$ As noted by prof. J. Bajda "It may turn out that 'reciprocity of consciences' will combine - as in the time of the prophet Elijah - four hundred false prophets, and the prophet of the True God will be left alone. And what if these false prophets are not only perfectly organized, but still armed with modern means of propaganda? According to Häring's philosophy, the individual should submit to the majority of 'mature consciences'. And what to do when this individual is the Pope?" (Bajda 1994, s. 33).

${ }^{3}$ Ibidem. 
ethics) to the doctrinal one. For example, Fr. Prof. Hans Küng confessed that "the whole dispute over the encyclical Humanae vitae opened his eyes to the fact that the Pope was not really about the «pill», but about the prestige of the office, continuity, authority and infallibility". ${ }^{4}$

The discussion about the encyclical was very dramatic also on the American continent. As in Europe, it polarized the extreme opinions of the antagonists and protagonists of the Church's teaching (Cf. Massa 2014).

The next anniversary, the $50^{\text {th }}$, opened up the discussion again. All the more so because one of the factors of this dynamics was the papal decisions of Francis on the establishing the Vatican commission aimed at re-reading the document of Paul VI. ${ }^{5}$

The anxiety associated with the setting of this commission results not only from its composition, ${ }^{6}$ but above all from certain words and gestures of the Bishop of Rome. The words of Francis, which he said in a plane returning from the Philippines in 2015, were highly acclaimed: "I mentioned a woman who was expecting an eighth child, already having seven caesarean-born births. This is irresponsibility. This woman could answer: «No, I trust in God». But look, God gives us the means to be responsible. Some people think that -

${ }^{4}$ D. Bruncz, Huragan i pole minowe - Humanae vitae ma 40 lat, http://www.ekumenizm.pl/ koscioly/katolickie/huragan-i-pole-minowe-humanae-vitae-ma-40-lat/ [accessed: 27.04.2018].

${ }^{5}$ The Vatican admits: The Humanae vitae commission is working. Will it allow contraception?, http://www.fronda.pl/a/watykan-przyznaje-pracuje-komisja-ds-humanae-vitae-dopusci-antykoncepcje,106278.html [accessed: 27.04.2018]; A. Sporniak, Antykoncepcja-utajniony problem?, https:// www.tygodnikpowszechny.pl/antykoncepcja-utajniony-problem-148178 [accessed: 27.04.2018]; A. Grajewski, „Humanae vitae” do dyskusji?, http://gosc.pl/doc/3994937.Humanae-vitae-do-dyskusji [state on 27.04.2018]; K. Kratiuk, Zamach na „Humanae vitae”. Rewanż po pół wieku?, https://www.pch24.pl/zamach-na-humanae-vitae--rewanz-po-pol-wieku-,52329,i.html [accessed: 27.04.2018].

${ }^{6}$ Particular attention is paid to the figure of Commission President Gilfredo Marengo. In September 2015, commenting in Vaticaninsider the Synod on the family, he was to encourage the abandonment of "the concept of doctrinal heritage of the Church"s as a closed system, insensitive to the questions and calla here and now, in which the Christian community finds expression of faith". In the same periodical (Vaticaninsider 23 March 2017), he published an article under the significant title Humanae vitae and Amoris Laetitia: parallel stories. He presents the view that the controversy of the pill-yes or the pill-not, as well as today's issue of communion for divorced is just an expression of "inconvenience and difficulty". They are not decisive in the light of the living tissue of the Church community. Marnego unambiguously indicates that, in the light of the proposed models based on too abstract and artificially constructed theological ideas, pastoral activity should be assumed as a new paradigm beyond the doctrinal one. The problem is that the contraceptive and sacramental dilemmas described by Marengo are not a controversial game, but they are an expression of the radical opposition of faith and morality. However, what is also important, Marengo did not postulate to read Amoris Laetitia in the line of hermeneutics of continuity. He does not deny the contradiction between the documents of Paul VI and Francis: he admits explicitly that Amoris Laetitia allows what Humanae vitae prohibits. Cf. R. Mattei, Il piano di "reinterpretazione" della Humanae vitae, https://www. corrispondenzaromana.it/il-piano-di-reinterpretazione-della-humanae-vitae/ [accessed: 27.04.2018]. 
sorry for the language - to be good Catholics, we must be like rabbits. No. Responsible parenthood " Less spectacularly, but noticeably, echoed other words of the Bishop of Rome, expressing the apology of one of the most prominent critics of the Humanae vitae, Fr. Prof. Bernard Häring, mentioned above. ${ }^{8}$

\section{Questioning moral objectivity and the deepest anthropological truth}

In this context of concern and lack of unambiguity, we should read the series of lectures on the encyclical of Paul VI, which has been taking place at the Pontifical Gregorian University in Rome since last year. ${ }^{9}$

At the same time, an analogous series of anniversary lectures on the subject of Humanae vitae is organized by another Roman university, Angelicum. The polarization of the positions presented so far at both universities is evidenced by current comments ${ }^{10}$ pointing to the collision of two concepts of the relationship of faith and morality, two concepts of doctrine and practice relations, two visions of the Church.

A special impression in this dispute was caused by the lecture of Fr. Prof. Maurizio Chiodi on December 14, 2017 at the Pontifical Gregorian University in Rome. The lecture was entitled Re-reading of Humanae vitae (1968) in the light of Amoris Laetitia (2016).

It must be remembered that Fr. Prof. Chiodi was appointed a new member of the Pontifical Academy of Life, which further legitimizes his views. In his lecture, prof. Maurizio Chiodi openly rejects the Church's moral doctrine regarding contraception. At the basis of this assessment there is a negation of the

${ }^{7}$ Quoted after A. Sosnowski, Sosnowski: The Vatican has a commission to revise Paul VI's Humanae vitae, https://wpolityce.pl/kosciol/380617-sosnowski-w-watykanie-dziala-komisja-ktorama-zrewidowac-humanae-vitae-pawla-vi [accessed: 27.04.2018].

${ }^{8}$ Cf. e.g.P. Baklinski, Francis praises major Humanae vitae dissenter in rebuke of 'white or black' morality, https://www.lifesitenews.com/news/francis-praises-prominent-humanae-vitae-dis senter-for-his-radical-new-moral [accessed: 27.04.2018]. J. Mirus, Pope Francis and Bernard Häring: The literally infernal cheek of dissent, https://www.catholicculture.org/commentary/otc. cfm?id=1455 [accessed: 27.04.2018]. G. Ariza, El Papa elogia a Bernard Häring, el mayor detractor de la Humanae vitae, https://infovaticana.com/2016/11/25/papa-elogia-bernard-haring-mayordetractor-la-humanae-vitae/ [accessed: 27.04.2018].

9 The program of lectures on the University website https://www.unigre.it/Univ/eventi/docu menti_17_18/614_PUG_FT_BIB_famiglia_programma.pdf; Cf. E. Pentin, Pontifical Gregorian University Hosts Series of Talks to Take New Look at Humanae vitae, http://www.ncregister.com/ blog/edward-pentin/gregorian-university-hosts-series-of-talks-to-take-new-look-at-humanae [accessed: 27.04.2018].

${ }^{10}$ Cf e.g. E. Barbieri, Gregoriana e Angelicum: due opposte voci sull'Humanae vitae, https:// anticattocomunismo.wordpress.com/2017/10/26/gregoriana-e-angelicum-due-opposte-voci-sullhu manae-vitae/\#more-11528 [accessed: 27.04.2018]. 
existence of a deep bond between the relationship of love and marital procreation, and that is logical. Chiodi in his lecture stated that under certain circumstances contraception is morally obligatory. ${ }^{11}$ In other words, his "responsible parenthood", specifically understood by him, can oblige a couple to use artificial birth control.

The statement by Maurizio Chiodi must be comprehended in the context of two out of five doubts (dubia) by four Cardinals, whose sense concerned the basic ambiguity expressed synthetically in the words: "In fact, there are no human acts that are intrinsically evil under all circumstances."

Chiodi argues in his speech that Amoris Laetitia is a new model and paradigm of moral theology, which eliminates the contention that contraception is an intrinsically evil act that is inappropriate at any place and time. It is impossible not to mention that such theses were presented by the documents of Paul VI and John Paul II - Humanae vitae, Familiaris consortio and Veritatis splendor.

Maurizio Chiodi, meanwhile, stated that there are "circumstances - I mean Chapter 8 of Amoris Laetitia - which make contraception obligatory because of responsibility. When natural methods are impossible or unenforceable, other forms of responsibility must be found". ${ }^{12}$

The presented thesis means in its essence an unambiguous defense of the consequential and proportionalist ethics that attacked Humanae vitae since its publication. The rejection of teaching that contraception is intrinsically evil means, in consequence, accepting the thesis that there are no intrinsically evil acts at all. Going further, it should be noted that every human action is determined in its moral nature only by the proportion between its good and evil effects.

The thesis posed by Maurizio Chiodi is very fundamental. It can not be understood only in the context of a dispute regarding the ethical assessment of contraception or responsible parenthood. The meaning of this statement con-

11 «Rileggere "Humanae vitae" (1968) a partire da "Amoris Laetitia" (2016)» è stato il titolo della relazione, nel corso della quale il professore ha spiegato: «La tecnica, in determinate circostanze, può consentire di custodire la qualità responsabile dell'atto coniugale anche nella decisione di non generare quando sussistano motivi plausibili per evitare il concepimento di un figlio. La tecnica, mi pare, non può essere rifiutata a priori quando è in gioco la nascita di un figlio, perché anche la tecnica è una forma dell'agire e quindi richiede un discernimento sulla base di criteri morali, irriducibili però a una interpretazione materiale della norma». A.M. Valli, L'etica delle situazioni. Un altro colpo di piccone all'insegnamento morale della Chiesa, https://apostatisidiventa.blogspot. com/2018/01/letica-delle-situazioni.html [accessed: 27.04.2018]; por. L. Bertocchi, "Contraccezione? In certi casi un dovere". Svolta in Vaticano, http://lanuovabq.it/it/contraccezione-in-certi-casiun-dovere-svolta-in-vaticano [accessed: 27.04.2018].

${ }^{12}$ Cf. Member of the Pontifical Academy of Life: in some cases, couples can use contraception, https://www.deon.pl/religia/kosciol-i-swiat/z-zycia-kosciola/art,32965,czlonek-papieskiej-ak ademii-zycia-w-pewnych-przypadkach-malzenstwa-moga-stosowac-antykoncepcje.html [accessed: 27.04.2018]. 
cerns the principals for the Christian ethics, and more specifically, ethics and moral theology.

These issues can be expressed in the form of several controversial theses put forward by the Italian theologian.

1' Norms of natural law "retain good and show the way of good, but they are historical". Such statement contradicts the eternal truth and validity of norms that contraception and many other activities are inherently evil, in a way that is not relative and dependent on historically changing opinions. Chiodi's views seem to suggest the possibility of interpretation, according to which Humanae vitae may have been true in 1968, but not in 2018 .

2' Although Chiodi does not explicitly state, he strongly suggests that the fact that many Catholic spouses use contraception and do not accept norms, proves that these norms are no longer valid, as if the majority consensus determined truth. In this way, it confirms the trend of sociological normalization, revealed during the creation of Humanae vitae and expressed in discussions about the primacy of "responsible consciences" over the "fossilized" doctrine of the Church. At the same time, it should be noted that recognizing the principle of majority consensus as a criterion of truth undermines the entire sphere of the culture of thinking based on the principle of objectivity of truth and cognitive abilities of human reason.

3' Maurizio Chiodi, claiming that some "circumstances - I mean Chapter 8 of Amoris Laetitia, - in a sense, in the name of responsibility, require contraception" - denies in fact directly the internal evil of contraception, taught by Paul VI, his predecessors and successors. Instead of this doctrine he introduces the suggestion that generally there are no intrinsically evil acts and that the moral quality of human action can never be determined universally "on a general basis", but depends on the proportions between good and bad consequences of human action in specific situations. ${ }^{13}$ As Prof. Seifert says, this opinion has nothing to do with blindness of conscience, the lack of ethical knowledge, or personal speculation often invoked by Rocco Buttiglione in the current debate. ${ }^{14}$

Chiodi assumes a completely objective "obligation of contraception" in certain situations. What are the consequences of such a view? Of course, contrary to all declarative defense, it means actual, real entry onto the path of situational ethics, which negates the tradition of objective and absolute norms. But you can not narrow down this destruction only to the ethical level. Fr. Prof. Maurizio Chiodi must be aware of it, when in a certain passage of his lecture

${ }^{13}$ Cf. Prof. Seifert about the shocking lecture of the Italian priest: the betrayal of the teaching of John Paul II, https://gloria.tv/article/XjJUQyqSEzzQ3vqGGE2cK6N9i [accessed: 27.04.2018].

${ }^{14} \mathrm{Cf}$. ibidem. 
he noted that the call to conceive should recognize the fact that "conception is not an act of creation", but "contains the answer to the gift and the recognition of the call to greet the presence of the other with gratitude". ${ }^{15}$

It is ambiguous to say that "conception is not an act of creation." It can be interpreted as a remark that the area of human corporeality, united in a matrimonial act, is a privileged area of love fully and integrally human, in which God passes with his creative act. But you can also interpret these words in such a way that these two realities - the creative act and the conception - are separable in the sense that there is no specific point of contact between them. It is puzzling that a theologian is silent about the fact that the answer to the gift is ultimately a response to the gift of the personal Donor, which is God, and this determines the moral obligation of a concrete answer.

A statement by Fr. Chiodi seems to sum up the earlier voices of the discussion, above all critical voices relating to the encyclical of Paul VI. Its value, however, is expressed in the fact that perhaps this statement opens the "reinterpretation" of the encyclical in the spirit of vague suggestions of the teaching of Pope Francis. All the more, it is necessary to recall the outline of the anthropological and theological truth underlying Humanae vitae which was carefully explored by Saint John Paul II.

\section{Primum anthropologicum et primum ethicum convertuntur}

A detailed analysis of Humanae vitae indicates the basic truths constituting the context in which the presented moral norms are embedded. However, it does not do this only cognitively. A human being in the face of truths that engage him existentially should feel obliged to recognize them unconditionally. This is what St. John Paul II said at the meeting with the world of science at the Catholic University of Lublin:

Man is a subject among the world of objects because he is able to objectify cognitively everything that surrounds him. Because of his mind, man he is turned "by nature" towards the truth. In the truth there is a source of human transcendence towards the universe in which he lives.

It is through reflection on one's own cognition that man reveals himself as the only being among the world that is seen connected with the learned truth "from the inside" - related, and therefore also "obliged" to recognize it, if necessary also by acts of free choice, by acts of testimony for the truth (Jan Pawel II 2005).

${ }^{15}$ Cf. A member of the Pontifical Academy of Life: in some cases, marriages may use contraception, art. cit. 
It is worth, and even must be remembered, taking into account a simple catalogue of truths underlying the Humanae vitae. They are necessary to be included in the analysis of the motivation of the encyclical norms.

The first of these is the recognition of the supremacy of objective moral criteria related to decisions regarding fertility and sexual life (there is a clear opposition to moral autonomy and subjectivism) (Cf. HV 10, 16; 7, 8, 13, 17, $18,20-21,30)$.

The second of these catalogued truths is the recognition of man's ability to know natural law by the power of his own reason (Cf. HV 12, 25, 10, 13, 17).

Another is recognition, as part of a realistic vision of man - the truth about the moral disorder and this makes it difficult to be faithful to the truth that has been recognized. It is this truth that indicates the most profound reasons for the existing contemporary conflict between the existence of an objective truth and the difficulty of its perception, and above all its assimilation (Cf. HV 9, $17,19,21,25)$.

Finally, the essential truth is that which demands the recognition of the moral value of a specific human act, which is a marital act, as assessed in the light of the call to parenthood and interpersonal love. The measure of contemporary marriage is not the current cultural context or social consensus in this respect, but this measure is the eternal and invariably valid plan of God (Cf. HV 25, 9, 11-12, 16).

Bearing in mind these fundamental truths - specific criteria for understanding the papal interpretation, we can try to explore the essence of the ethical marriage act.

Briefly, we can grasp this essence with a Catholic thesis stating that the moral meaning is contained not only in the human person, able to pass on life, but also in the ability of the spouses to procreate. What does it mean? In this way, the Church indicates that in sexual intercourse there is order coming from God. These two elements are extremely important here - the confirmation of the objective order that describes sexual intercourse and the relationship of this act with God. This can be read in the relevant passage of the encyclical:

uniting husband and wife in the closest intimacy, also renders them capable of generating new life - and this as a result of laws written into the actual nature of man and of woman. And if each of these essential qualities, the unitive and the procreative, is preserved, the use of marriage fully retains its sense of true mutual love and its ordination to the supreme responsibility of parenthood to which man is called. (HV 12).

Thus, the marital relationship is characterized by a double purpose: first, it expresses the intended purpose of a sexual intercourse (destinatio) to "express 
and strengthen the spouses' union", and at the same time points to the purpose "to pass on human life" (HV 11).

"From this point of view, in an intercourse there is a "two-fold significance» (originally significatio) namely «indicating unity and indicating parenthood». Between these two meanings of an intercourse there is the same «unbreakable bond established by God» (HV 12), and between its two objectives" (Comment, p. 40)

It can therefore be seen that, in its essence, the structure of a marital sexual intercourse is directed in a definite way and serves human beings to express love. However, it gives this love a definite shape, which means that it poses specific and precise demands. In this way, the sexual nature of the marital bond and related biological laws become a part of a human person (Cf. HV 10).

In other words, a sexual intercourse of the spouses (comprising in a complementary way two essential elements, that is indicating unity and parenthood), as well as the structure of marriage, understood as a union of fertile love, which reveals and indicates an inalienable dependence on the source of love, i.e. "God, who is Love and the Father" - both these elements point to the inalienable, constitutively important cooperation with the love of God, the Creator of human life.

This cooperation is not, as Fr. Chiodi wants, only "response to the gift and recognition of the call to greet the presence of the other with gratitude". It is much more, it has a constitutive character. Such is the role of truth, available by the power of human reason - this truth known in the act of self-discovery, causes self-determination. A man living by this truth can survive, experience self-fulfillment. On the contrary, rejecting this truth means the risk of selfdestruction - self-annihilation.

Karol Wojtyła was fully aware of this when he included in the Commentary to the Encyclical the words:

This relationship is so strict that deliberately depriving an intercourse of one of these elements takes away the whole meaning of the other element, which makes the relationship cease to be a sign of love. Marital love expresses itself in a sexual intercourse not only in connection with sexual function, but through it: the relationship consists in the union of reproductive organs. On the other hand, the parental function should, by the will of God, have its source in personal love, characterized by the desire "to enrich someone else with a gift of oneself" (HV 9), which consciously "goes towards his extension and the awakening of new life" (ibidem), seeing in parenthood "a very lofty task to which man is called" (HV 12) (Comment, p. 41). 
It is for this reason that any marital relationship should express acceptance for the marital call to imitate God-Love and God-Life. For the same reasons, it should be noted that the magnitude of this appeal to carry out a vocation requires, equally, the spouses' resignation from any claims for each of them. Being a selfless gift should be treated with all the seriousness of the truth of the term. It should also be noted that the requirements posed by Humanae vitae result above all from the acceptance of the dual meaning inherent in marriage - indicating unity and indicating parenthood.

This rich in spiritual and intellectual heritage tradition of theological thought of the Church, was once again expressed by John Paul II in his catechesis concerning the so-called "theology of the body". In one of them we read:

As dispensers of the sacrament, which is fulfilled through conjugal union, man and woman are called to utter this mysterious speech of their bodies in the whole truth that suits them, through all gestures and reactions, through all the conditioning of the tension and satisfaction which is the direct source and subject of the body in its masculinity and femininity, the body in action and interaction, through all this "speaks" man: person.

Man and woman lead in the "body speech" that dialogue that began on the day of creation according to Genesis 2: 24-25. And it is at the level of this "body language", which is more than just sexual reactivity itself, and which as the real speech of persons is subject to the requirements of truth, they express themselves mutually. They express themselves more fully and deeply than the very somatic dimension of masculinity and femininity permits: they express themselves within the entire truth about the person.

Man is a person because he owns and controls himself. Just as much as he "owns" himself, he can "give" himself to another (Jan Paweł II 1986, p. 473).

The above text is an expression of the original, and at the same time consistently defined theology of the body, which is an element of papal adequate anthropology. It is possible to indicate there basic foundations of theological and anthropological thought, which become necessary for understanding the deep meaning of the lecture of Paul VI and his interpretation of John Paul II, referring to the theological vision of marriage and parenthood:

1 ' The starting point here is the conciliar text on the dignity of the human person, which is treated with undisguised predilection by Saint John Paul II. According to the Constitution Gaudium et spes, man is the only visible creature that God wanted "for him alone" and who "can not find himself otherwise than through a selfless gift of himself" (Cf. Gaudium et Spes 24). In the light of this special anthropological criterion, it can be seen that gift is the basic vocation of man, his destiny, and at the same time a very important dignity criterion. 
The gift reveals, so to speak, a particular characteristic of personal existence, or rather, of the essence of the person. When God-Yahweh said, "It is not good that man should be alone", (Gn 2:18) he affirmed that "alone", man does not completely realize this essence. He realizes it only by existing "with someone" - and even more deeply and completely - by existing "for someone". ${ }^{16}$

2' The reality of gift implies specific dynamics in the human person and in external relations. This means that "to be with" and "to be for", that is communion and giving, remain in a close and inseparable connection with the human body. Therefore, the body can not be treated as a mere set of organs and functions, but as a "sign" revealing the person and the "place" of realizing that person. "The body which expresses femininity «for» the masculinity and vice versa the masculinity «for» the femininity, manifests the reciprocity and communion of persons». It expresses it by means of the gift as the fundamental characteristic of personal existence". ${ }^{17}$

3' Communion and giving accomplished with the help of the "sign" of the body are realized in interpersonal conjugal love, "whose "truth» lies in mutual personal donation (self-giving as a person), and thus in giving totally (as the person is a unity - undivided and indivisible)" (Tettamanzi 1993, p. 140).

4' A special (though not the only) act of conjugal love is the sexual intercourse: "it is an act in truth, when conjugal love - of which it is a fruit and a sign - is transmitted in truth" (Ibidem, p. 141). Hence, if the truth of a sexual intercourse is mutual giving of spouses, and nothing of this giving can be excluded, preventing pregnancy is a falsification of this act. St. John Paul II therefore states: "contraceptive action introduces a fundamental limitation to the interior of this mutual giving and expresses the intentional evasion of giving the other the whole good of femininity or masculinity. In short: the truth of conjugal love" (Jan Paweł II 1999a, p. 252).

5 ' The nature of marital being a mutual gift is specific. It is the inseparability of the relationship between the intra-matrimonial (between spouses) and extra-marital (between parents and children) giving (Cf. FC 14). That is why, consistently, contraception in this context becomes a denial and also a falsification of the truth of conjugal love as an "extra-marital" gift. But at the same time, such an act becomes an entering the relationship between parents and God the Creator. And here we touch the most theological (in the sense logically indicating to God) issue:

${ }^{16}$ John Paul II, General audience 09.01.1980, http://w2.vatican.va/content/john-paul-ii/en/audiences/1980/documents/hf_jp-ii_aud_19800109.html [accessed: 13.01.2019].

${ }^{17}$ Ibidem. 
The beginning of every human person is the creative act of God: no human existence is a matter of chance; man is always the goal of God's creative love. From this basic truth of faith and reason it follows that the ability to procreate, inscribed in the sexuality of man, is - in its deepest truth - cooperation with the creative power of God. From this truth it also follows that man and woman are not arbiters of this ability, they are not its owners; they are called in it and through it to participate in the creative decision of God (Jan Paweł II 1999a, p. 251).

This must be emphasized here once again: Saint John Paul II therefore settles the problem of regulating the conception in the most deeply and literally theological context: "having a child is an event which is deeply human and full of religious meaning, insofar as it involves both the spouses, who form "one flesh" (Gen 2:24), and God who makes himself present" (EV 43; cf. Gaudium et Spes 50). In other words, more concisely, but at the same time brilliantly bluntly and literally: biological and theological unity is inscribed in the act of giving birth initiated at the moment of conception: "the genealogy of the person is inscribed in the very biology of generation" (Ibidem; cf. Letter to Families Gratissimam sane 9).

Two sentences in an extremely synthetic and dramatic way probably express the heart of the dispute around Humanae vitae. One of them expressed directly by Fr. prof. Chiodi acknowledges that conception is not an act of creation. The second, resulting from the thoughts of Fr. prof. Karol Wojtyla, presented by him with the power of his papal authority, states: "genealogy of a person is inscribed in the biology of generation". It seems that between the poles of this dispute there is not only a discussion and controversy about the norms of marital life ethics. It is not even a dispute between the so-called "new moral theology" referring to ethical consequentialism and the measure of subjective conscience, and objective morality, indicating the need to correlate conscience with the moral law. It is probably in its deepest essence a dispute between theology containing hidden anti-theism and theology as the teaching of faith. For this reason it is a dispute to which a believing theologian can not remain indifferent. 
"THE GENEALOGY OF THE PERSON IS INSCRIBED IN THE VERY BIOLOGY OF GENERATION". TOWARDS THE HEART OF THE DISPUTE ON HUMANAE VITAE

\section{Summary}

Since the publication of the encyclical Humanae vitae by Paul VI in 1968, a heated discussion has been taking place around this document. It comes alive in a particularly intense way on the occasion of the subsequent anniversaries of the publication of the document. Subsequent decades showed a number of problems related not only to the ethics of marital life and sexual ethics, but also to the concept of conscience or recognition or rejection of the seriousness of the Church's Magisterium. Recent months have brought further opinions of antagonists and protagonists of this document.

Among opponents or critics of the encyclical, there are views questioning the teaching that contraception is intrinsically evil. This, in consequence, means accepting the thesis that there are no intrinsically evil acts at all. What is more, it should be noted that every human action is determined in its moral nature only by the proportion between its good and bad effects.

In confrontation with these views, the article presents an outline of the anthropological and theological truth underlying Humanae vitae which was analysed with insight by St. John Paul II. This allows for the extraction of several basic theses relating to the theological vision of marriage and parenthood: (1) to read the truth about marriage and parenthood, it is necessary to fully recognize the truth about the dignity of the human person, (2) the person realizes fully in the reality of the gift that creates interpersonal communion with the participation of the human body, (3) communion and endowment made with the help of the "sign" of the body are realized in interpersonal conjugal love, (4) the special (though not the only) act of conjugal love is a sexual act, (5) marital logic of being a mutual gift is specific and this is inseparability of the bond between the inter-marital gift (between spouses) and the non-marital gift (between parents and children). Ultimately, this leads to the thought of St. Pope John Paul II, ordering to combine the order of the marriage act with the creative act "the genealogy of the person is inscribed in the very biology of generation".

Keywords: Humanae vitae; the ethics of marital life; theology of the body; anthropology; procreation

Słowa kluczowe: Humanae vitae; etyka życia małżeńskiego; teologia ciała; antropologia; prokreacja 


\section{BIBLIOGRAPHY}

Bajda J. (1994), Wolność a prawda w encyklice ,Veritatis splendor”, „Studia Theologica Varsaviensia" 32, no 1, p. 25-38.

Jan Paweł II (1999a), Chrześcijańskie powołanie matżonków może wymagać także heroizmu. Do uczestników seminarium „Odpowiedzialne rodzicielstwo”, in: Nauczanie papieskie VI, 2 1983, Poznań, p. 250-253.

Jan Paweł II (1999b), Familiaris consortio. Adhortacja apostolska o zadaniach rodziny chrześcijańskiej w świecie współczesnym, in: Posoborowe dokumenty Kościoła Katolickiego o matżeństwie i rodzinie, vol. 1, wybór i wstęp K. Lubowicki, Kraków, p. 133-238.

Jan Paweł II (1986), Mężczyzną i niewiasta stworzyt ich. Odkupienie ciała a sakramentalność matżeństwa, Città del Vaticano.

Jan Paweł II (2005), Odpowiedzialność za prawdę poznawana i przekazywana. Przemówienie Ojca Świętego do świata nauki KUL, Aula im. Stefana Kard. Wyszyńskiego, 9 VI 1987, in: Jan Paweł II, Pielgrzymki do Ojczyzny 1979 - 1983 - 1987 - 1991 - 1995 - 1997 - 1999 - 2002. Przemówienia, homilie, Kraków, p. 394-402.

Massa M.S. (2014), The American Catholic Revolution: How the Sixties Changed the Church Forever, New York.

Tettamanzi D. (1993), Encyklika „Humanae vitae” w nauczaniu Jana Pawła II, Communio” 13, no 3 (75), p. 136-148.

Wojtyła K. (1969), Komentarz teologiczno-duszpasterski do „Humanae vitae”, Rzym.

\section{Publikacje internetowe}

Ariza G., El Papa elogia a Bernard Häring, el mayor detractor de la Humanae vitae, https://infova ticana.com/2016/11/25/papa-elogia-bernard-haring-mayor-detractor-la-humanae-vitae/ [accessed: 27.04 .2018$]$.

Baklinski P., Francis praises major Humanae vitae dissenter in rebuke of 'white or black' morality, https://www.lifesitenews.com/news/francis-praises-prominent-humanae-vitae-dissenter-forhis-radical-new-moral [accessed: 27.04.2018].

Barbieri E., Gregoriana e Angelicum: due opposte voci sull'Humanae vitae, https://anticattocomu nismo.wordpress.com/2017/10/26/gregoriana-e-angelicum-due-opposte-voci-sullhumanaevitae/\#more-11528 [accessed: 27.04.2018].

Bertocchi L, "Contraccezione? In certi casi un dovere". Svolta in Vaticano, http://lanuovabq.it/it/ contraccezione-in-certi-casi-un-dovere-svolta-in-vaticano [accessed: 27.04.2018].

Bruncz D., Huragan i pole minowe - Humanae vitae ma 40 lat, http://www.ekumenizm.pl/koscioly/ katolickie/huragan-i-pole-minowe-humanae-vitae-ma-40-lat/ [accessed: 27.04.2018].

Członek Papieskiej Akademii Życia: w pewnych przypadkach matżeństwa moga stosować antykoncepcje, https://www.deon.pl/religia/kosciol-i-swiat/z-zycia-kosciola/art,32965,czlonek-pap ieskiej-akademii-zycia-w-pewnych-przypadkach-malzenstwa-moga-stosowac-antykoncepcje. html [accessed: 27.04.2018].

Grajewski A., „Humanae vitae” do dyskusji?, http://gosc.pl/doc/3994937.Humanae-vitae-do-dys kusji [accessed: 27.04.2018].

Gyapong D., Humanae vitae receives new respect 40 years later, https://www.catholicregister.org/ home/international/item/9652-humanae-vitae-receives-new-respect-40-years-later [accessed: 27.04.2018].

Jan Paweł II, Evangelium vitae, in: http://w2.vatican.va/content/john-paul-ii/en/encyclicals/docu ments/hf_jp-ii_enc_25031995_evangelium-vitae.html [accessed: 13.01.2019].

John Paul II, Letter to Families Gratissimam sane, in: http://w2.vatican.va/content/john-paul-ii/en/ letters/1994/documents/hf_jp-ii_let_02021994_families.html [accessed: 13.01.2019]. 
John Paul II, General audience 9 I 1980, in: http://w2.vatican.va/content/john-paul-ii/en/audien ces/1980/documents/hf_jp-ii_aud_19800109.html [accessed: 13.01.2019]

Kratiuk K., Zamach na „Humanae vitae”. Rewanż po pół wieku?, https://www.pch24.pl/zamach-na-humanae-vitae--rewanz-po-pol-wieku-,52329,i.html [accessed: 27.04.2018].

Mahoney K., Humanae vitae: 40 years later, still about love, https:/www.catholicnewsagency.com/ resources/life-and-family/humanae-vitae/humanae-vitae-40-years-later-still-about-love [accessed: 27.04.2018].

Mattei R., Il piano di "reinterpretazione" della Humanae vitae, https://www.corrispondenzaroma na.it/il-piano-di-reinterpretazione-della-humanae-vitae/ [accessed: 27.04.2018].

Mirus J., Pope Francis and Bernard Häring: The literally infernal cheek of dissent, https://www. catholicculture.org/commentary/otc.cfm?id=1455 [accessed: 27.04.2018].

Paul VI, Humanae vitae, in: http://w2.vatican.va/content/paul-vi/en/encyclicals/documents/hf p-vi enc 25071968 humanae-vitae.html [accessed: 13.01.2019].

Pentin E., Pontifical Gregorian University Hosts Series of Talks to Take New Look at Humanae vitae, http://www.ncregister.com/blog/edward-pentin/gregorian-university-hosts-series-of-talksto-take-new-look-at-humanae [accessed: 27.04.2018].

Prof. Seifert o szokujacym wykładzie włoskiego duchownego: zdrada nauczania Jana Pawła II, https://gloria.tv/article/XjJUQyqSEzzQ3vqGGE2cK6N9i [accessed: 27.04.2018].

Shaw R., Message Refused: Humanae vitae, 40 Years Later, https://www.crisismagazine.com/2008/ message-refused-humanae-vitae-40-years-later [accessed: 27.04.2018].

Sosnowski A., W Watykanie działa komisja, która ma zrewidować „Humanae vitae” Pawła VI, https://wpolityce.pl/kosciol/380617-sosnowski-w-watykanie-dziala-komisja-ktora-mazrewidowac-humanae-vitae-pawla-vi [accessed: 27.04.2018].

Sporniak A., Antykoncepcja - utajniony problem?, https://www.tygodnikpowszechny.pl/antykon cepcja-utajniony-problem-148178 [accessed: 27.04.2018].

Tyree S., The vindication of Humanae vitae: 40 years later, http://www.stltoday.com/lifesty les/faith-and-values/civil-religion/the-vindication-of-humanae-vitae-years-later/artic le_369a1cf3-8558-5988-9c70-50ee177b4fbd.html [accessed: 27.04.2018].

Valli A.M., L'etica delle situazioni. Un altro colpo di piccone all'insegnamento morale della Chie sa, https://apostatisidiventa.blogspot.com/2018/01/letica-delle-situazioni.html [accessed: 27.04.2018].

Watykan przyznaje: Pracuje komisja ds. Humanae vitae. Dopuści antykoncepcję?, http://www.fron da.pl/a/watykan-przyznaje-pracuje-komisja-ds-humanae-vitae-dopusci-antykoncepcje, 106278. html [accessed: 27.04.2018].

Pawel Bortkiewicz TCH - kapłan i teolog, profesor zatrudniony na UAM w Poznaniu i WSKSiM w Toruniu, autor kilku książek i wielu artykułów, publicysta katolicki. 